\title{
Local Site Effects Evaluation Using Microtremor Measurements at North Side of Pandan Mountain
}

\author{
Samsul Hidayat ${ }^{1}$, Dwa Desa Warnana ${ }^{2}$, Sorja Koesuma ${ }^{1}, \mathrm{C} \mathrm{Cari}^{1}$ \\ ${ }^{1}$ Physics Department of Graduate Program, Sebelas Maret University, Surakarta \\ ${ }^{2}$ Geophysical Engineering Department, Institut Teknologi Sepuluh Nopember, Surabaya \\ E-mail: cak.syam.hidayat@gmail.com
}

Received 21 August 2017, Revised 18 September 2017, Accepted 28 September 2017

\begin{abstract}
Disaster mitigation has been undertaken to reduce the impact of loss or damage caused by the earthquake. For disaster mitigation purpose, it is necessary to conduct a local geological assessment. The horizontal to vertical spectral ratio (HVSR) of microtremor analysis is very popular in the context of seismic micro-zonation. Microtremor method is cheap, data acquisition is easy, and does not cause noise, so suitable for use in residential areas. This research aims to determine the distribution of the natural frequency value, the amplification factor value, and the soil vulnerability index value. This study was conducted geographically between $7^{\circ} 26^{\prime} 17.45^{\prime \prime}$ - $7^{\circ} 26^{\prime} 53.16^{\prime \prime} \mathrm{S}$ and $111^{\circ} 47^{\prime} 14.76^{\prime \prime}-111^{\circ} 48^{\prime} 7.06^{\prime \prime}$ E. Data processing using HVSR analysis method on Easy HVSR software. The results showed that the natural frequency $\left(f_{o}\right)$ values range $0,95 \mathrm{~Hz}$ to $8,3 \mathrm{~Hz}$ and the amplification factor values range 2,05 to 8,67 . From the result data of the natural frequency and the amplification factor, the soil vulnerability index can be calculated. The vulnerability index $(\mathrm{Kg})$ value ranges from 1,09 to 68,33 . The northeast side of the study area is indicated as a weak zone where have high potential to damage when the earthquake occurred.
\end{abstract}

Keyword: Microtremor, HVSR, soil vulnerability index

\section{Introduction}

East Java is one of the provinces in Indonesia that has a high risk of the earthquake disaster because East Java is close to the zone line of subduction and also many faults (local faults) which have not been identified accurately (Susilo and Adnan, 2013). The Bojonegoro district is one of the districts located in the administrative area of East Java province. During 2016, there are 73 earthquake events occur on the Pandan mountain and surrounding, mostly happening on the north side of Pandan mountain (Hidayat et al, 2017). Some buildings were damage due to the earthquake as shown in Figure 1 and Figure 7. This study area focused on a north of Pandan mountain.

Evaluation of earthquake hazard is necessary to mitigate actual damage due to an activity of seismic. Seismic hazard assessment includes: determining sources of seismic, studying the micro-zonation, estimating the local site effect and identifying the structural weakness (Khalda et al, 2015). The large ground motion amplification during 
earthquakes may be caused the local site characteristics (Warnana et al, 2011). The seismic wave trapping phenomenon leads to amplified tremor amplitudes that may increase hazard in sites with soft sediment soil. Microtremor study has proved an effective tool for assessment of sites effects in cases of simple or complex geological structure (Gosar, 2007). Microtremor or called ambient noise is a vibration of ground that caused by the natural event or artificial event e.g. the wind, trees, waves, footsteps, a vibration of industrial machine or vehicles that can reflect the geological conditions near the surface (Susilo and Wiyono, 2012). The horizontal to vertical spectral ratio (HVSR) or called the Nakamura technique has been adopted for the microtremor data analysis to determine the natural frequency $\left(f_{o}\right)$ and the amplification factor $\left(A_{g}\right)$ of a site (Nakamura, 1989). Microtremor data analysis is also applied in the identification of the soil layers, prediction of a velocity of a shear wave of the ground, and assessment of the predominant period of the soil during earthquake events and determinant of sediment thickness (Adib et al, 2015, Pratiwi et al, 2017). To identify the weak zone during an earthquake, Nakamura (1997) proposed the vulnerability index $\left(K_{g}\right)$ as a link between the natural frequency $\left(f_{o}\right)$ and the amplification factor $\left(A_{g}\right)$ in the formula $\mathrm{K}_{\mathrm{g}}=\left(\mathrm{A}_{\mathrm{g}}\right)^{2} / \mathrm{f}_{\mathrm{o}}$. This study aims to determine the local site characteristics of the Krondonan village and surrounding using the Nakamura technique (HVSR method) of microtremor and the soil vulnerability index value to predict weak zone at the study area.

\section{The Study Area}

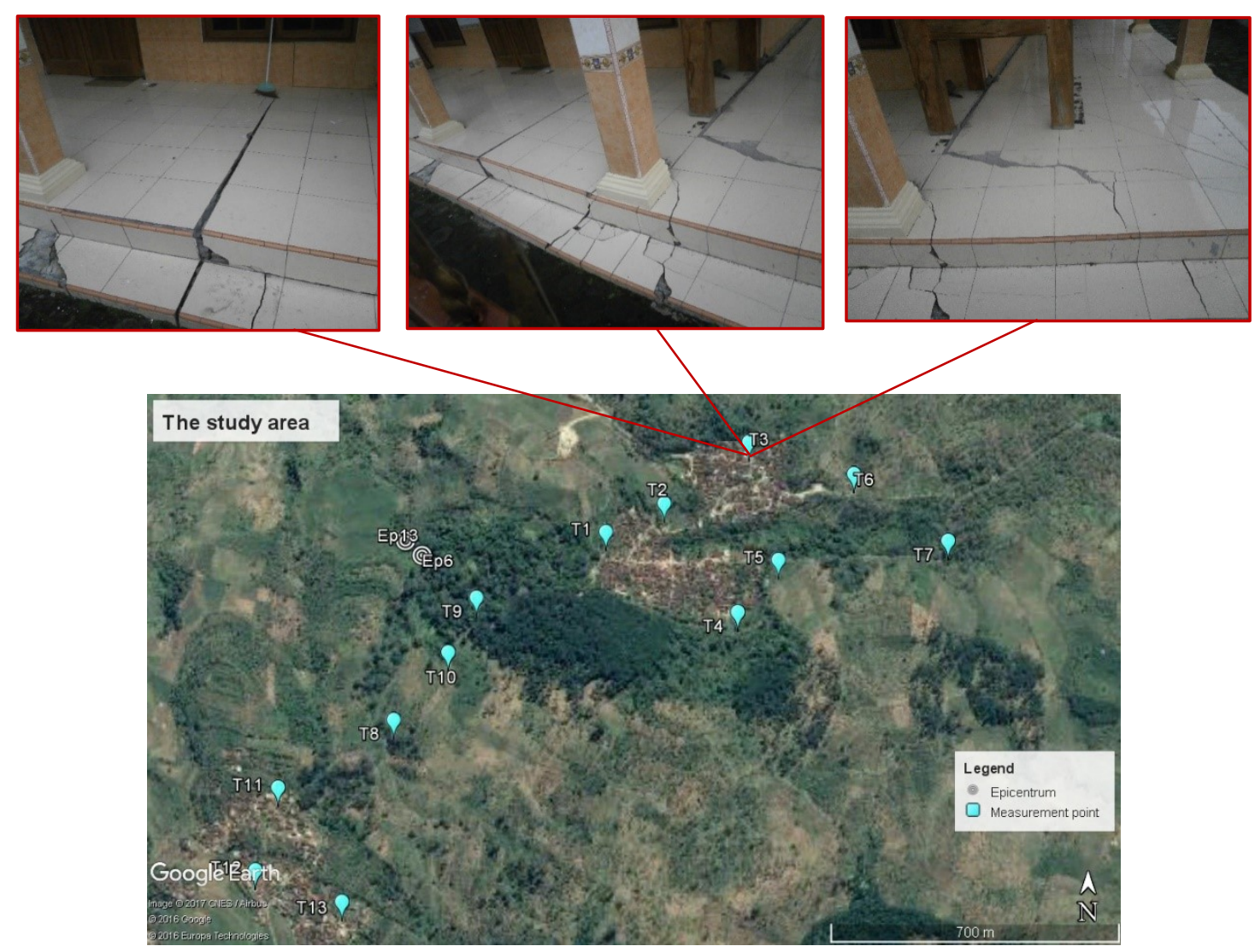

Figure 1. The study area and phenomenon of damage of the building in the study area 
Measurement microtremor data were conducted in Krondonan village and surrounding, north of Pandan mountain, Bojonegoro district. The geographically ranges

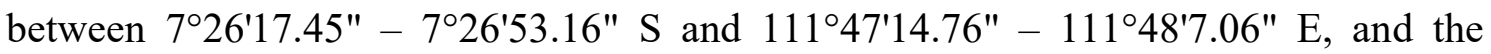
elevation ranges between $478 \mathrm{~m}$ and $528 \mathrm{~m}$.

Pandan mountain is a Quaternary mountain formed in Early Pleistocene. The rock unit of the study area is dominated by the breccia of volcanic (Hidayat et al, 2017). The peak ground acceleration of the study area ranged from $0,175 \mathrm{~g}$ to $0,2 \mathrm{~g}$ shown in Figure 2. Santoso et al (2017) explain that Pandan mountain is one of the mountains that state as a dormant volcano. But there is still existing body magma under the surface of Pandan mountain. Hot spring and warm ground have been found to be an indication of sub magmatic activity.

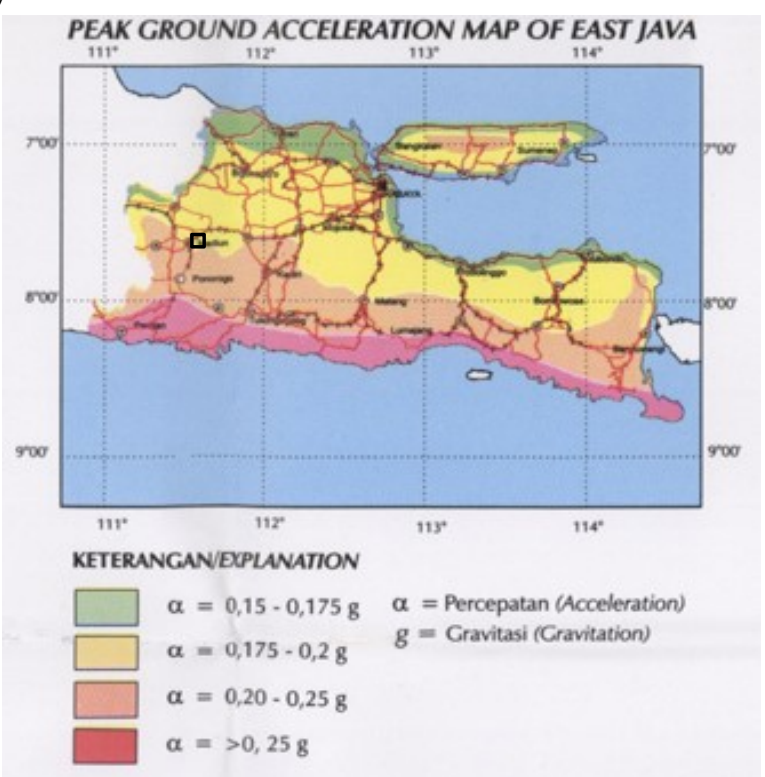

Figure 2. Peak ground acceleration of East Java (study area is shown by black box)

(Supartoyo and Djaja, 2010)

\section{Data Acquisition}

Microtremor observations were performed using portable microtremor equipment in February 2017. Microtremor data were recorded as single-point measuring using portable seismograph 3-components SL07 SARA single-station. This device has a 24bit channeled digitizer, a central processing unit (CPU) AVR RISC processor 11,592 $\mathrm{MHz}$ and a GPS receiver. Data acquisitions conducted on 13 measurement points spread in Krondonan village and surrounding. Their locations were carefully selected to avoid the influence of trees and sources of monochromatic noise. At each measurement point, it was recorded during 30 minutes (18000 s) microtremor data with $100 \mathrm{~Hz}$ sampling rate of frequency. During the recording process, the device was located on level ground and was balanced.

\section{Data Processing and Analysis}

The technical guidelines of the SESAME European research project (SESAME, 2004) were used for the implementation of the Nakamura technique (HVSR method) for 
microtremor. The data processing has been done using two software, the first one is Geopsy software version 2.9.1 which was used to convert the data format from EV (EV0, EV1, EV2) format to SESAME ASCII format (*.saf). The second software is the Easy HVSR software version 2014.16.2.155 which is designed to process and calculate the spectral ratio of the horizontal to vertical $(\mathrm{H} / \mathrm{V})$ components from ambient vibration record.

The data result of ambient vibration record still contains transient signal. Each component of the recorded signal was windowed in a time series of $40 \mathrm{sec}$ window length. Windowing process was used to reject parts of the transient signal, characterized by an amplitude higher than the ambient vibration. The fast Fourier transform (FFT) process has been applied to change the time domain into the frequency domain. The smoothing process is done by using the Konno\&Ohmachi logarithmic window function. To obtain HVSR curve, the two horizontal components must be one value using the square average. Then calculated the average ratio of horizontal component to vertical component $(\mathrm{H} / \mathrm{V})$. HVSR analysis of 13 free-field microtremor measurements in the study area showed that most of them fulfill the criteria defined by SESAME European research project (SESAME, 2004) for reliable curve H/V and reliable peak.

\section{Results and Discussion}

The HVSR curve contains the natural frequency $\left(f_{o}\right)$ value and the amplification factor $\left(A_{g}\right)$ value. Nakamura (1997) proposed the vulnerability index as an indicator weak point of ground that may amplify the ground motion. The vulnerability index $\left(K_{g}\right)$ parameter is a combination of $f_{o}$ and $A_{g}$ using the equation: $K_{g}=\left(A_{g}\right)^{2} / f_{0}$.

\subsection{Distribution of Natural Frequency}

Nakamura (2000) explained that the natural frequency contains information of thickness of sediment layer (depth of bedrock). The smaller of $f_{o}$ value, the greater of a thickness of sediment layer. Figure 3 shows the distribution of $f_{o}$ values in the study area ranging from $0,95 \mathrm{~Hz}$ to $8,3 \mathrm{~Hz}$.

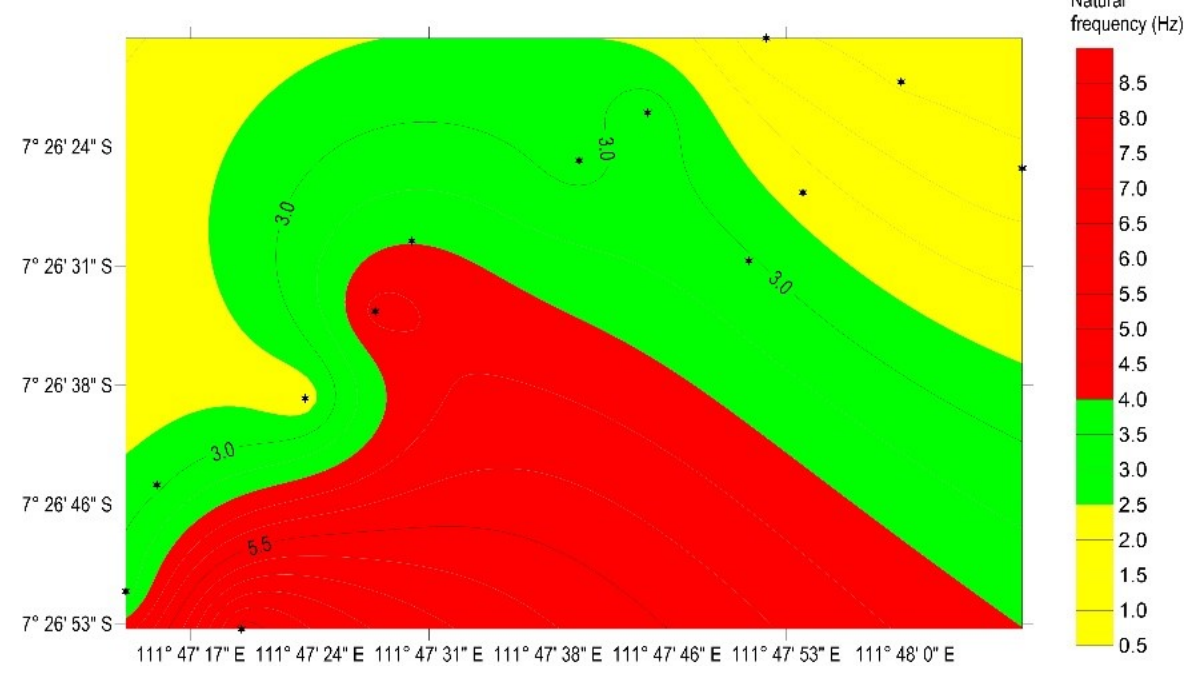

Figure 3. Distribution of the natural frequency value in the study area 
The natural frequency data were divided into three categories: low (marked yellow zone), medium (marked green zone), and high (marked red zone). The yellow zone indicates in this area the sediment layer is thicker than the other zone (green zone and red zone).

\subsection{Distribution of Amplification Factor}

Nakamura (2000) explained that amplification factor is related to impedance ratio between bedrock and sediment layer. Figure 4 shows a distribution of the amplification factor (peak HVSR curve) in the study area varied from 2,05 to 8,67. Figure 5 shows that measurement point of T3 and measurement point of T8 has a high value compared to the other point of measurements.

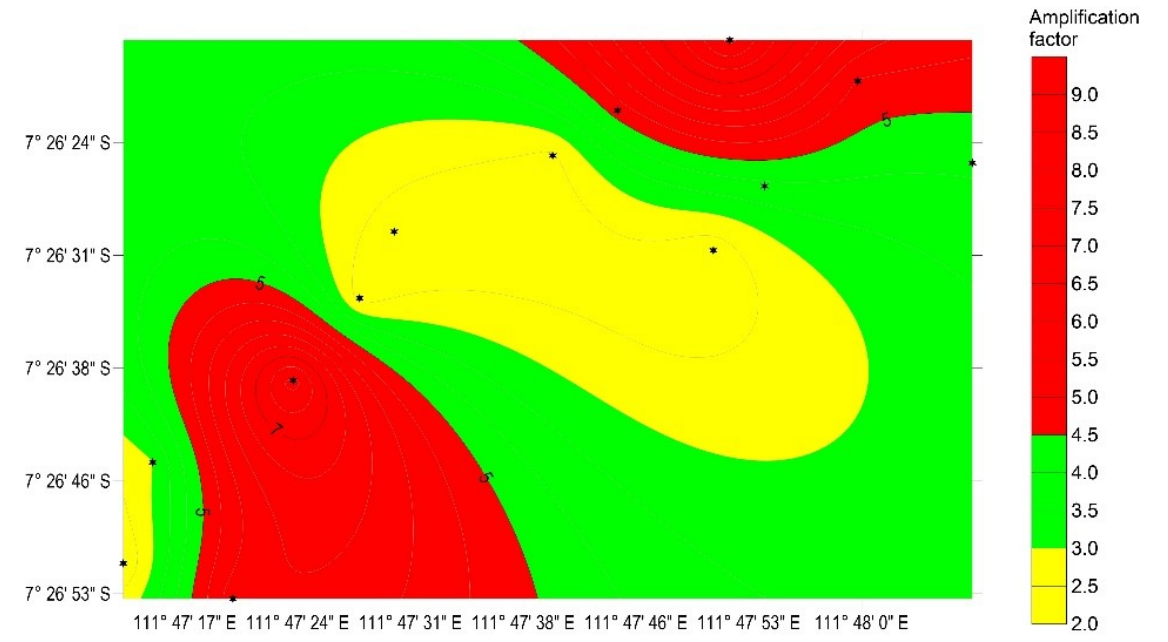

Figure 4. Distribution of the amplification factor value in the study area

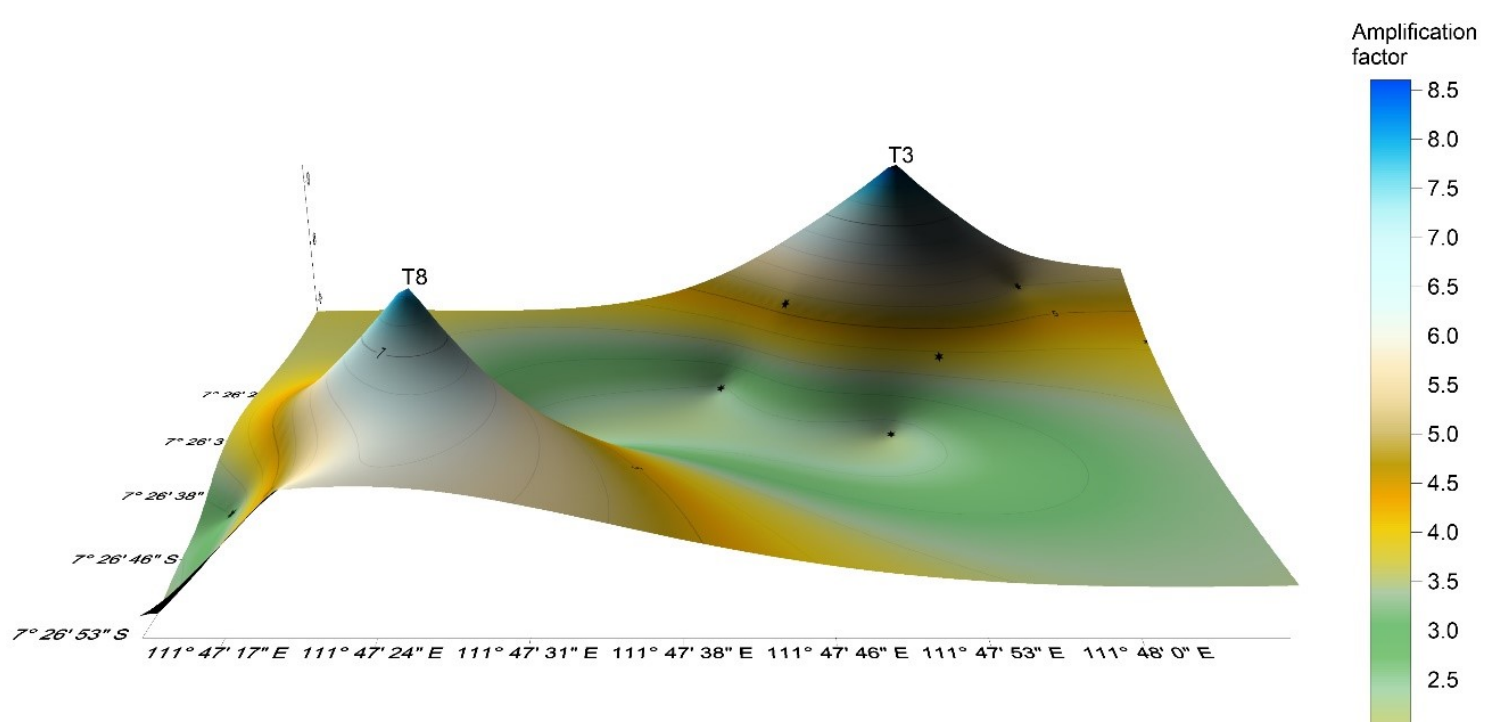

Figure 5. Distribution of the amplification factor value in the study area in three dimensions (3D) 


\subsection{Distribution of Soil Vulnerability Index}

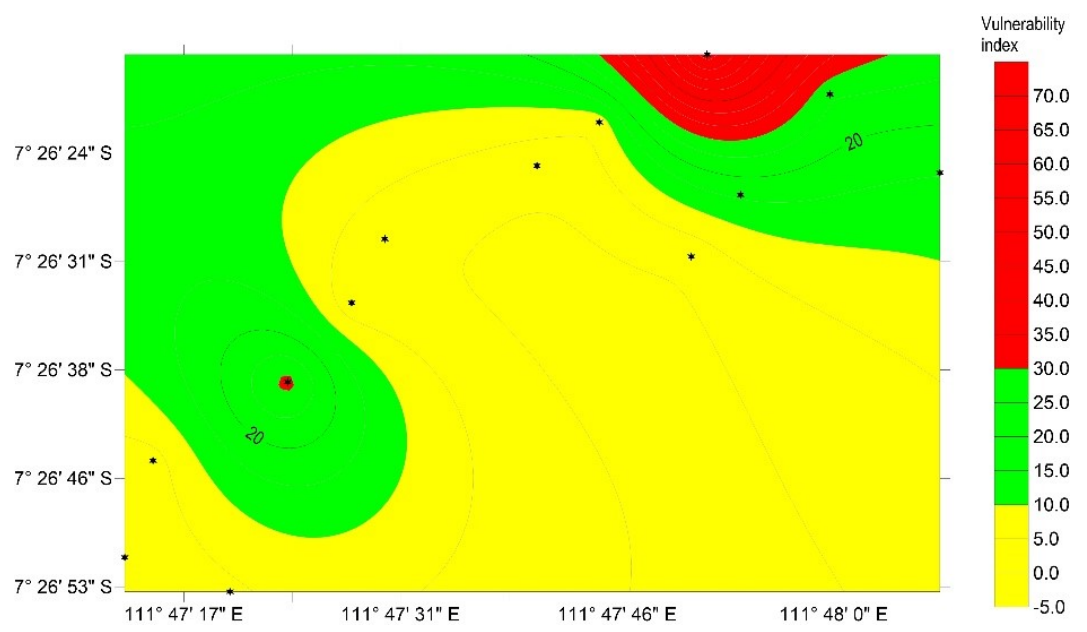

Figure 6. Distribution of the soil vulnerability index value in the study area

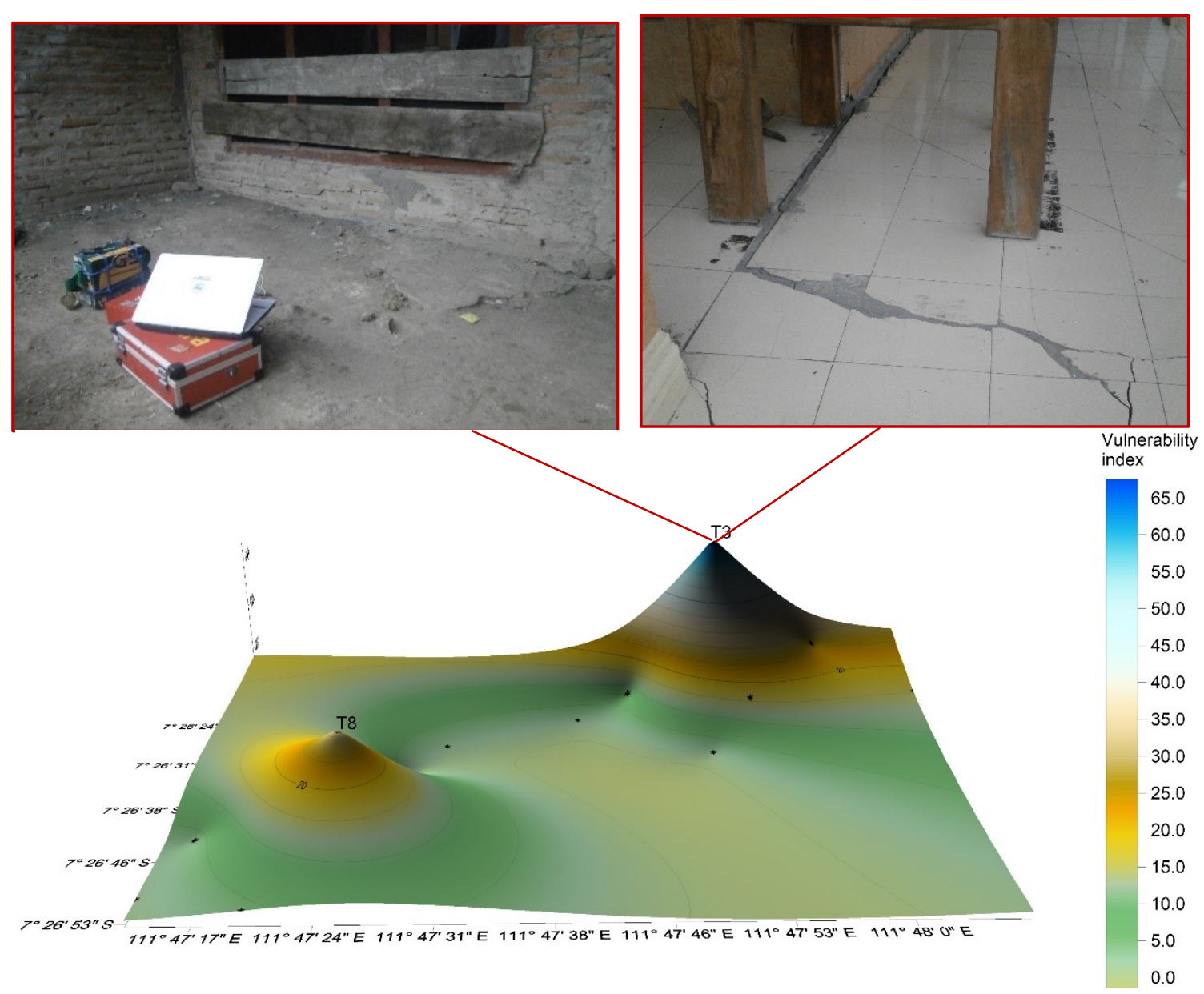

Figure 7. Distribution of the soil vulnerability index value in the study area in three dimensions (3D) and phenomenon of damage of the building in the study area

The vulnerability index value reflects local site effect and can be considered as an indicator which might be useful in selecting a weak point of ground (Warnana et al, 2011). Distribution of the soil vulnerability index values in the study area ranging from 
1,09 to 68,33 shown in Figure 6. Figure 7 shows that measurement point of T3 has the highest soil vulnerability index value, meaning that in this zone has the highest level of vulnerability to earthquake shocks among other zones. There is a relationship between the soil vulnerability index level with the damage level of the building in the study area (Figure 1 and Figure 7). The high soil vulnerability index values are associated with serious damage to the building.

\section{Conclusion}

The study was carried out by recording the ambient vibration of microtremor at 13 sites spread in Krondonan village and surrounding, north of Pandan mountain. The natural frequency $\left(f_{o}\right)$ and the amplification factor $\left(A_{g}\right)$ were obtained and the soil vulnerability index was calculated based on these parameters. The natural frequency values ranging from $0,95 \mathrm{~Hz}$ to $8,3 \mathrm{~Hz}$ and the amplification factor values varied from 2,05 to 8,67 . In this study, the soil vulnerability index values ranging from 1,09 to 68,33 . The final results of this study that the northeast side (measurement point of T3) of the study area as indicated as a weak zone, a prone area of earthquake shake.

\section{Acknowledgements}

The authors would like to thank the Geophysics undergraduate program, Institut Teknologi Sepuluh Nopember Surabaya for providing the microtremor equipment. In addition, the authors acknowledge Pak Munib and Mas Pegri for their help in field measurements.

\section{References}

Adib, A., Afzal, P., Heydarzadeh, K. (2015) Site Effect Classification Based on Microtremor Data Analysis Using a Concentration-area Fractal Model. Nonlin. Processes Geophys., 22, 53-63.

Gosar, A. (2007). Microtremor HVSR Study for Assessing Site Effects in the Bovec Basin (NW Slovenia) Related to $1998 \mathrm{Mw}$ 5,6 and $2004 \mathrm{Mw}$ 5,2 Earthquakes. Engineering Geology, 91, 178-193.

Hidayat, S., Warnana, D.D., Koesuma, S., Cari. (2017). Seismic Microzonation by Using Microtremor Method in Pandan Volcano, Bojonegoro, East Java. J. Phys.: Conf. Ser. 909 012031. Doi:10.1088/1742-6596/909/1/012031

Khalda Y. Ibrahim, Abu Eleia A. Mohamed, Insaf S. Babiker, Abdel Hafiz G. Elmula. (2015). Local Site Effects Evaluation for Atbara Area Using Microtremor Measurements. American Journal of Earth Sciences, Vol. 2, No. 5, pp. 134141.

Nakamura, Y. (1989). A Method for Dynamic Characteristics Estimation of Subsurface using Microtremor on the Ground Surface. Quarterly Report of Railway Technical Research Institute, Vol.30, No.1.

Nakamura, Y. (1997). Seismic Vulnerability Indices for Ground and Structures Using Microtremor. World Congress on Railway Research, Florence, November, pp. $1-7$. 
Nakamura, Y. (2000). Clear Identification of Fundamental Idea of Nakamura's Technique and Its Applications. World Conferences on Earthquakes Engineering (12WCEE). Auckland, 30 January - 4 February 2000.

Nugraha, A..D., Supendi, P., Shiddiqi, H. A., Widiyantoro, S. (2016). Unexpected Earthquake of June $25^{\text {th }}, 2015$ in Madiun, East Java. AIP Conference Proceedings. 1730 020001. Doi:10.1063/1.44947369

Pratiwi, S., Legowo, B., Koesuma., S. (2017). Penentuan Tingkat Kerawanan Gempa Bumi Menggunakan Metode Refraksi Mikrotremor (ReMi) di Kota Surakarta. Indonesian Journal of Applied Physics, Vol. 7, No. 1, pp. 59-65.

Santoso, D., Wahyudi, E.J., Alawiyah, S., Nugraha, A.D., Widiyantoro, S., Kadir, W.G.A., Supendi, P., Wiyono, P., Zulkafriza. (2017). Subsurface Structure Interpretation Beneath of Mt. Pandan Based Garivity Data. IOP Conf. Series: Earth and Environmental Science. 62 012038. Doi:10.1088/1755$1315 / 62 / 1 / 012038$

SESAME. (2004). Guidelines for the Implementation of the H/V Spectral Ratio Technique On Ambient Vibrations, Measurements, Processing, and Interpretation. SESAME European Research Project. WP12-deliverable D23.12.

Supartoyo \& Djaja. (2010). Earthquake Hazard Zone Map of East Java Province. Center for volcanology and geological hazard mitigation, a ministry of energy and mineral resources.

Susilo, A. and Adnan, Z. (2013) Probabilistic Seismic Hazard Analysis of East Java Region, Indonesia. International Journal of Computer and Electrical Engineering, Vol. 5, No. 3, pp. 341-344.

Susilo, A. and Wiyono, S.H. (2012) Frequency Analysis and Seismic Vulnerability Index by Using Nakamura Methods at a New Artery Way in Porong Sidoarjo, Indonesia. International Journal of Applied Physics and Mathematics, Vol. 2, No. 4, pp. 227-230.

Warnana, D.D., Soemitro, R.A.A., Utama, W. (2011). Application of Microtremor HVSR Method for Assessing Site Effect in Residual Soil Slope. International Journal of Basic \& Applied Sciences IJBAS-IJENS, Vol.11, No. 4, pp. 73-78. 